\title{
THE YEAR 1848 IN FRANCE. A FEW REMARKS AT THE 170TH ANNIVERSARY OF THE ADOPTION OF THE CONSTITUTION OF THE SECOND FRENCH REPUBLIC IN 1848 PART I
}

\author{
Marcin Konarski*
}

\begin{abstract}
This article is a synthetic analysis of the events of the Spring of Nations in France, which preceded the adoption of the Constitution of the Second French Republic on 4 November 1848. The author presents the main causes of the revolutionary events, the course of these events until 1848 as well as the most important legal reforms of political and social nature undertaken during that period.

Key words: Spring of Nations, 1848, Provisional Government, socialism, social reforms, right to work, abolition of slavery, abolition of death penalty, universal voting rights
\end{abstract}

The year 2018 marks the 170th anniversary of the adoption of the ninth ${ }^{1}$ Basic Law in the history of French constitutionalism, which was

\footnotetext{
Doctor of legal sciences - Assistant Professor at the Department of Administration, Faculty of Social Sciences and Administration, Warsaw Management University.

1 In chronological order, the Basic Laws preceding the Constitution of 1848 were: the Constitution of 3 September 1791, the Constitution of 24 June 1793 (the so-called Jacobinical Constitution) Constitution of 22 August 1795, (so-called Directorial Constitution or 5 fructidor of year III), Constitution of 13 December 1799 (the so-called Consular Constitution or the Constitution of 22 frimaire VIII), the Constitution of 18 May 1804 (28 floreal XII), the Constitutional Charter of 4 June 1814, the Additional Act to
} 
the outcome of the events of 1848 in Europe, commonly known as the Spring of Nations. The Constitution of the French Second Republic of 4 November $1848^{2}$ is an exceptionally interesting area of research, for at least three reasons.

Firstly, the months preceding its adoption led to a change of the state's political system, which had existed in France from $1815^{3}$. The period before the adoption of the Second French Republic, i.e. between 1814-1848 was characterised by a system that had grown up on the basis of the reaction that was a result of a compromise between the monarchy and the aristocracy and the nascent capitalist class, i.e. the bourgeoisie ${ }^{4}$. This period can be divided into the system of the Bourbon Restoration (1814-1830) and the system of the July Monarchy $(1830-1848)^{5}$, but the two periods were in fact not different, because during both periods the plutocracy along with the King and the Parliament were in power ${ }^{6}$. The revolutionary events of the months preceding the adoption of the Constitution of 4 November 1848 overthrew the aforementioned system in the name of democratic, and, at some point, even socialist slogans ${ }^{7}$.

the Empire Constitution of 22 April 1815 and the Constitution of 14 August 1830, see D. Turpin, Droit constitutionnele, Paris 1992, pp. 263-293, which does not, however, mention the Additional Act of 1815 .

2 The text of the Constitution: https://www.conseil-constitutionnel.fr/les-constitutions-dans-1-histoire/constitution-de-1848-iie-republique [retrieved: 19 September 2018].

3 A. de Tocqueville wrote that "the most important reason why ruling classes lose power is always the fact that "they become unworthy to hold power", idem, Wspomnienia, translated by A.W. Labuda, Wrocław 1987, p. 17.

4 As A. Esmein emphasizes, the constitutional monarchy (1814-1848) tried to imitate the English parliamentarianism, which at that time was already well known, see idem, Zasady prawa konstytucyjnego, translated by K. Lutostański, W. Konopczyński, Warszawa 1904 , p. 58.

5 See M. Czernyszewski, Monarchia lipcowa, In: idem, Wybór pism historycznych, translated by F. Borkowska, M. Wawrykowa, Wrocław 1959, pp. 301-346.

6 See K. Grzybowski, Demokracja francuska, Kraków 1947, p. 60.

7 See A. de Tocqueville, op. cit., pp. 89-91. C. Schmitt claimed that scholarly awareness of socialism did not appear until after the year 1848, which was a breakthrough moment, because from that time on "the socialist movement gained political significance, and its supporters could think that one day they would really put their ideals into practice", idem, Teologia polityczna i inne pisma, translated by M.A. Cichocki, Warszawa, 2012, p. 201. 
Secondly, the Constitution of 1848 introduced completely new solutions concerning the structure of the state authority in the form of the President of the Republic ${ }^{8}$.

Thirdly, the Constitution in question was toppled by the coup of Louis-Napoléon on 2 December 1851, i.e. in a non-legal way, which incidentally was not an exceptional phenomenon in the history of French constitutionalism?.

For modern European constitutionalism the events of 1848 and 1849 were of particular importance because it is the first case in history when during only one year so many European states adopted new Basic Laws, despite the fact that revolutionary events in different countries took place under different conditions and had disparate backgrounds ${ }^{10}$.

Let us just mention that as early as on 10 February 1848, the King of the Kingdom of two Sicilies, Ferdinand II, announced a constitution ${ }^{11}$, and was then followed by the King of Sardinia, Charles Albert, who, on

8 During the debate on the draft constitution, aforementioned A. de Tocqueville called for the election of the President by direct voting to be relinquished, and for this activity to be entrusted to special representatives elected by the people, which he explained by the fear that "the people will be governed by blindness and will succumb to moods", idem, op. cit., p. 211.

9 The coup d'état which took place on 18 brumaire VIII (9 November 1799) enabled Napoleon Bonaparte to overthrow the constitution which created the Directory, see M. Konarski, Zamach stanu w perspektywie prawno-historycznej na przykładzie Rewolucji Francuskiej 1789-1799, In: Przestępstwa przeciwko bezpieczeństwu i porządkowi publicznemu, ed. W. Lis, Lublin 2017, pp. 54-57.

10 See M. Handelsman, Rok 1848: przegląd zagadnień międzynarodowych, „Przegląd Historyczny” 1948, no. 38, pp. 7-36.

11 See T. Maciejewski, Konstytucjonalizm okresu Wiosny Ludów na obszarze Italii, „Gdańskie Studia Prawnicze. Studia z historii ustroju i prawa” 2006, no. XV, pp. 67-68. It is generally assumed that revolutionary events associated with the Spring of Nations began in Palermo, Sicily in January 1848. The city of Palermo rebelled against the Neapolitan rule on January 121848 and this rebellion quickly spread to the whole province under the slogan of constitution and autonomy for Sicily, see S. Kieniewicz, Oblicze ideowe Wiosny Ludów, Warszawa 1948, p. 63; J.A. Gierowski, Historia Włoch, Wrocław 1999, p. 378. Although the revolution in Italy was chronologically the first on the European continent, it should be stressed that it was France that gave a battle cry for a general uprising of peoples in the West, and its model triggered a general national and democratic movement in Europe, which with few exceptions, conquered all European countries. 
4 March, announced the "Basic Statute of the Kingdom" modelled on the French Constitution of $1830^{12}$. This statute was the only constitution that was still in force in Italy after 1849, becoming later (after 1861) the binding constitution across the entire territory of Italy until 1925. Sardinia was followed by Tuscany, where, on 15 February, the Grand Duke of Tuscany imposed a constitution, thus eliminating absolutist rule ${ }^{13}$, and on 10 July 1848 r. King Ferdinand II announced the constitution of Sicily ${ }^{14}$.

In Hungary, a series of laws of a constitutional nature (March Laws), creating a new constitutional order ${ }^{15}$, approved by the Emperor ${ }^{16}$, were passed on March 11th. On 25 April, the Emperor vested a constitution to Austria, which, however, was to apply only to the so-called hereditary countries, thus recognising Hungary's separateness, which was logical, since Hungary already had its own state on the basis of a constitution sanctioned by the monarch ${ }^{17}$. In addition, the Austrian Constitution did not mention its Italian dominions. That was because the form in which they belonged to the Empire had not been established yet and was to be settled by means of military action ${ }^{18}$. Although Vienna made temporary concessions to Hungary ${ }^{19}$, it was clearly preparing for an armed trial of strength. When Austria finally withdrew from the recognition of Hungary's independence, it led to the proclamation of the republic and the dethronement of the Habsburgs and the outbreak of an armed uprising ${ }^{20}$, which was brutally suppressed by Russian troops sent by Tsar Nicholas I ${ }^{21}$.

12 See T. Maciejewski, Konstytucjonalizm okresu Wiosny Ludów..., pp. 62-65.

13 See J.A. Gierowski, Historia..., p. 378.

14 See T. Maciejewski, Konstytucjonalizm okresu Wiosny Ludów..., pp. 67-68.

15 See I. Deak, The Lawful Revolution. Louis Kossuth and the Hungarians 1848-1849, New York 1979, pp. 81-106; W. Felczak, Historia Węgier, Wrocław 1983, pp. 225-230.

16 See T. Maciejewski, Konstytucjonalizm habsbursko-niemiecki okresu Wiosny Ludów, „Gdańskie Studia Prawnicze. Studia z historii ustroju i prawa” 2006, no. XV, pp. 46-47.

17 See ibidem, pp. 39-41

18 See H. Wereszycki, Historia Austrii, Wrocław 1986, p. 203.

19 See J.M. Boldenyi, Dzieje Węgier pod względem historycznym, artystycznym, literackim i społecznym, Warszawa 1863, pp. 235-236.

20 One should remember that the revolutionary events in Hungary were connected by the national isssue. The Hungarian nobility oppressed Slovaks, Serbs, Romanians, Croatians and Ukrainians, while they demanded freedom for themselves for the Habsburgs. Almost until the end of the revolution the Hungarians denied the nations they oppressed 
For Austria itself, however, the adoption of the Constitution - as a completely undemocratic law that, above all, was passed due to the monarch's will ${ }^{22}$, led to the outbreak of the second revolution in Vienna in May 1848, which resulted in the suspension of the Constitution on 16 May 1848 (a day before a huge demonstration against the Constitution had taken place), the resignation of Ferdinand I as well as the government, and the announcement of a new election to the parliament, which was to adopt a constitution on the basis of universal and equal suffrage, which was considered a victory for the revolutionary principle of sovereignty ${ }^{23}$.

Next, the National Constitutional assembly, which gathered in the summer residence of Archbishop Olomouc - Kroměríž in Moravia, from 13 January to 3 March $1849^{24}$, was dissolved before the adoption of a new constitution ${ }^{25}$, which was finally imposed by the Emperor, but which did not come into force, as it was revoked by the Emperor with an imperial

- except the Croatians - the freedoms that they demanded for themselves from Vienna, see J. Baszkiewicz, Wolność. Równość. Własność. Rewolucje burżuazyjne, Warszawa 1981, p. 117.

21 Under the Warsaw Convention of 22 May 1849 the tsar undertook to send 180000 troops to Hungary. The tsarist army was to operate on its own and independently of the Austrian army, which, however, in the light of A. Divéky's message was dictated by the fears of the Russians of the outbreak of a possible Polish revolution, so the tsar reserved the independence of his army's movements, so that if necessary he could immediately withdraw it from Hungary and move to Galicia or Poland, see A. Divéky, Węgrzy a Polacy w XIX stuleciu, Warszawa 1919, p. 98. The last Hungarian troops laid down their arms on 27 September 1849, followed by trials of the insurgents on 7 October 1849, in which many of them were sentenced to death, see J. Bułharyn, Rys wojny węgierskiej w latach 1848 i 1849, Paris 1852, pp. 369-371.

22 See R.A. Kann, A history of the Habsburg empire 1526-1918, Berkeley 1974, p. 301.

${ }^{23}$ See H. Wereszycki, op. cit., p. 204.

24 See R.A. Kann, op. cit., p. 308.

25 In addition to the main point of the deliberations, the aim of which was, as we said, to a liberal constitution, there was the intricate question of a multinational state that would safeguard the free development of individual nationalities, all the more so as individual nations within a monarchy "considered themselves to be nations destined to rule, state nations in the sense that their existence required a separate statehood", H. Wereszycki, Pod berłem Habsburgów. Zagadnienia narodowościowe, Kraków 1975, p. 109. The draft of this constitution was analysed by T. Maciejewski, see idem, Konstytucjonalizm habsbursko-niemiecki..., pp. 42-45. 
patent of 31 December 1851. The patent brought about the liquidation of civil rights and freedoms as constitutional norms. He left only one principle, namely equality before the law, stating clearly that it means first of all the abolition of all peasant dependence on subjection and the benefits associated with it. Thus, the Spring of Nations in Austria was not followed by a permanent constitutional order, and since 1852 the neo-absolute way of governing returned ${ }^{26}$.

At that time in Prussia, King Frederick William IV, although reluctant to embark on the constitutional path ${ }^{27}$, announced a relatively progressive constitution on 5 December $^{28}$. However, after containing the situation in the country ${ }^{29}$, which was reviewed and announced in a new formula on

26 See A. Dziadzio, Koncepcja państwa prawa w XIX wieku - idea i rzeczywistość, „Czasopismo Prawno-Historyczne” 2005, no. 1, p. 193.

27 See J. Wąsicki, Związek Niemiecki i państwa niemieckie 1815-1848, Poznań 1986, p. 455; S. Salmonowicz, Prusy: dzieje państwa i społeczeństwa, Warszawa 2004, p. 303.

28 See J.A.R. Marriot, Ch.G. Robertson, The evolution of Prussia, the making of an empire, Oxford 1915, pp. 318-321. The Constitution guaranteed equality before the law and freedom of the press, association, teaching and religion. In addition, it introduced a bicameral parliament and the responsibility of ministers before this parliament. The Second Chamber was to be elected by universal, yet indirect, suffrage, but in the voting to the Second Chamber it established a property census, which, as J. Kosim stresses, "enabled the representatives of the wealthy bourgeoisie to take their seats next to the nobility", idem, Prusy i inne kraje niemieckie po kongresie wiedeńskim, In: Europa i świat w epoce restauracji, romantyzmu i rewolucji 1815-1849, ed. W. Zajewski, Volume I, Warszawa 1991, p. 360. According to F. Engels, "In Prussia the Chambers gathered in February in order to review and approve the new constitution proclaimed by the king. They met for about six weeks, quite submissive and humble in their attitude to the government, but not as obedient as the king and his ministers would have wished. They were therefore resolved at the first opportunity," idem, Rewolucja i kontrrewolucja w Niemczech, In: K. Marks, F. Engels, Dzieła, Volume VIII, Warszawa 1964, p. 90.

29 Let us remember that the Frankfurt Parliament adopted the Constitution of the German Empire on 28 March 1849. However, the governments of nearly all German states (Prussia, Saxony, Bavaria, Hessia, et. al) did not agree to recognise it, which triggered an uprising in the Rhineland, Dresden, Baden, the Palatinate in which small-bourgeois democrats led the way. F. Engels presents the course of this uprising, Niemiecka kampania o konstytucję Rzeszy, In: K. Marks, F. Engels, Dzieła, Volume VII, Warszawa 1963, pp. 125-231. For more about the Constitution of the German Empire see M. Wawrykowa, Dzieje Niemiec 1789-1871, Warszawa 1980, pp. 368-369; T. Maciejewski, Konstytucjonalizm habsbursko-niemiecki..., pp. 56-60; A. Dziadzio, Koncepcja państwa prawa..., pp. 183-185. 
31 January 1850, remaining in force until the November Revolution of $1918^{30}$. It should also be emphasized here that it is in the draft of the Frankfurt Constitution of 1849 and the March Constitution for Austrian countries that the "political projection of the rule of law (Rechtsstaat), which was created by German liberal thought and the science of state law" may be noticed ${ }^{31}$. As A. Dziadzio adds, "although they did not enter into force, they determined in a visionary way the direction of political transformations in both Germany and Austria for almost a hundred years"32. Although some of the basic laws passed during the revolutionary turmoil of 1848-1849 did not stand the test of time, they inevitably began the process of European states entering the path of modern constitutionalism.

The events that the European continent experienced in 1848 and 1849 , took place indirectly because of the crop failure and potato infestation in 1845 and $1846^{33}$, which led to bloody clashes, both in France and on the whole continent, i.e. everywhere where the effects of the crop failure were transformed into anti-government hunger strikes ${ }^{34}$. In addition, the outbreak of the Spring of Nations can also be blamed directly on the general financial, commercial and industrial crisis in Britain ${ }^{35}$, whose first symptoms appeared in the form of mass crash of speculators dealing in railway shares ${ }^{36}$. However, the crisis became severe as late as in Au-

30 See T. Maciejewski, Konstytucjonalizm habsbursko-niemiecki..., pp. 49-51.

31 A. Dziadzio, Ochrona konstytucyjności prawa w Europie XIX wieku, „Studia z Dziejów Państwa i Prawa Polskiego" 2008, no.11, p. 170.

32 Ibidem, p. 170.

33 Cf. K. Marks, F. Engels, Przegląd wydarzeń. Maj-październik 1850 r., In: idem, Dzieła, Volume VII, Warszawa 1963, p. 497; E. Kaczyńska, K. Piesowicz, Wykłady z powszechnej historii gospodarczej (od schyłku średniowiecza do I wojny światowej), Warszawa 1977, p. 350.

34 See M. Wąsowicz, Między tronem, giełdą i barykadą. Francja 1830-1848, Warszawa 1994, pp. 270-271.

35 See K. Marks, F. Engels, Przegląd wydarzeń..., pp. 497-502; J. Ciepielewski, I. Kostrowicka, Z. Landau, J. Tomaszewski, Dzieje gospodarcze świata do roku 1970, Warszawa 1974 , p. 87.

36 See K. Marks, F. Engels, Przegląd wydarzeń..., pp. 496-498; E.M. Jones, Jałowy pieniądz: historia kapitalizmu jako konfliktu między pracą a lichwą. Volume III: od 
tumn 1847, with the bankruptcies of major London merchants of colonial goods, immediately followed by crashes of agricultural banks and closures of factories in English industrial regions, In France, a full-blown economic crisis became noticeable in Spring $1847^{37}$.

The demands made in that period include, above all, the demands of political reforms: the introduction of a constitutional monarchy or a republic, the extension of electoral rights (lowering of the electoral census) ${ }^{38}$, a ban on combining the parliamentary mandate with public functions, autonomy or independence of peoples under foreign rule. The second type of demands in this period is related to social issues, i.e. social welfare, the reduction of working hours, universal and free education, etc. It should be remembered that this was a period when the legal and economic situation of the working class was one of the most tragic in modern history ${ }^{39}$.

This was due to very low salaries and a 14-15 hour working day, which pushed the human body to its limits. Moreover, women and children were employed on a massive scale, and the lack of any hygiene, social care,

Wielkiego Głodu do krachu roku 2008, translated by J. Morka, Wrocław 2015, pp. 57-59. The number of people in Britain for whom - along with members of their families - the railways constituted their livelihoods ranged between 600000 and 1 million.

W. Rusiński, Zarys historii gospodarczej powszechnej. Czasy nowożytne i najnowsze (1500-1949), Warszawa 1973, p. 245. The first banks on the Continent which financed the construction of railways or constructed them themselves did not start to appear until the revolution of 1848, see J. Kuliszer, Powszechna historia gospodarcza średniowiecza i czasów nowożytnych, Volume II, Warszawa 1961, p. 538.

37 See N. Gąsiorowska, Sytuacja gospodarczo-społeczna na zachodzie i wschodzie Europy w połowie XIX stulecia, In: W stulecie Wiosny Ludów 1848-1948, ed. N. Gąsiorowska, Warszawa 1948, p. 14; P. Vigier, La Seconde République, Paris 1970, pp. 17-18; M. Wąsowicz, op. cit., pp. 272-273. For more about the economic situation in France before 1848 see G. Weill, La France sous la monarche constitutionnelle (1814-1848), Paris 1912, pp. 208-237.

38 Cf. Ch. Seignobos, Dzieje polityczne Europy współczesnej. Rozwój stronnictw i form politycznych 1814-1899, ed. J. Stecki, Warszawa 1900, p. 148. A. de Tocqueville, however, who saw the need to reform the electoral law and to reform the parliament in general, wrote that "it is not a legal mechanism that creates great events but the spirit of the government itself”, idem, op. cit., p. 19.

39 See A. Zahorski, Francja w latach 1815-1848. Restauracja i Monarchia Lipcowa, In: Europa i świat w epoce restauracji, romantyzmu i rewolucji 1815-1849, ed. W. Zajewski, Volume I, Warszawa 1991, pp. 278-280. 
protection against illness and death, as well as housing conditions that were insulting to human health and dignity made the situation that prevailed at the time in all branches of industry exactly the same as at the end of the $18^{\text {th }}$ century ${ }^{40}$.

Therefore, two main historical causes of the 1848-1849 revolution should be indicated ${ }^{41}:$ (1) the overthrow of absolute monarchies and their replacement by constitutional monarchies, the abolition of feudal land ownership, the liberation from foreign rule and the creation of uniform nation states; (2) the growing contradictions between developing capitalism and the absolutist-feudal relations, typical for the Middle Ages, that were still dominant in most European states ${ }^{42}$. A. Lewak complements this catalogue with the observation that the strongest aspiration of the Spring of Nations was to create larger state units, to unite societies in nation states, which resulted directly from the development of economic conditions at that time ${ }^{43}$.

Let us now look at the most significant events of the French Spring of Nations which preceded the adoption of the Constitution on 4 November 1848. The first serious riot took place in Paris on 22 February 1848, where

40 See F. Engels, Listy z Wuppertalu, In: K. Marks, F. Engels, Dzieła, Volume I, Warszawa 1960, pp. 647-669; idem, Położenie klasy robotniczej w Anglii. Na podstawie własnych obserwacji i autentycznych źródeł, In: K. Marks, F. Engels, Dzieła, Volume II, Warszawa 1961, pp. 263-597. F. Mehring emphasises that "no one before Marx was able to present the suffering of the modern proletariat in such a strikingly authentic way", idem, Historia socjaldemokracji niemieckiej, Volume I, translated by E. Werfel, Warszawa 1963, p. 418.

${ }^{41}$ See S. Kurt, The Revolutions of 1848 and its reflections to modern political mentality, ,Journal of History School” 2014, Year 7, Issue XVIII, pp. 362-365 [http://dx.doi. org/10.14225/Joh506].

42 E. Hobsbawm emphasies that "the pan-European economic cataclysm coincided with a sharp crisis of the old order", idem, Wiek rewolucji 1789-1848, translated by M. Starnawski, K. Gawlicz, Warszawa 2013, p. 452.

43 A. Lewak, Emigracja Polska wobec rewolucji 1848/9 r., In: Pamiętnik VII Powszechnego Zjazdu Historyków Polskich we Wrocławiu 19-22 września 1948. Referaty, Volume I, Warszawa 1948, p. 323. 
a crowd of people gathered. The crowd was very nervous because of the prolonged crisis and raging unemployment. A bloody clash with government units did not yet take place, and the crowd was dispersed by the army without human casualties ${ }^{44}$, but during the following days many incidents involving the police and the army took place. As we know, on 24 February in Paris, King Louis Philip decided to abdicate in favour of Prince Philippe of Orléans the Count of Paris, who was his minor grandson and whose mother, the Duchess of Orléans was to take over the regency, King Louis Philip then left the palace ${ }^{45}$.

The Chamber of Deputies, appalled by the course of events and deliberating under pressure from the insurgents, did not recognise the Count of Paris and handed over full power to the 11-member Provisional Government, which had been born on the barricades and by its very nature reflected various parties in its composition ${ }^{46}$. The Provisional Government issued the Proclamation to the French Nation, which stated that "A reactionary and oligarchical government has just been overthrown by the heroism of the people of Paris. That government has fled, leaving behind it a trail of blood that forbids it ever to retrace its steps. The blood of the people has flowed as in July" ${ }^{47}$; but this time this noble people shall not

44 See F. Ziegler, Paryż i jego rewolucje, translated by H. Łochocka, Warszawa 1972, p. 77; F. Engels, Rewolucja w Paryżu, In: K. Marks, F. Engels, Dzieła, Volume IV, Warszawa 1986, pp. 732-733.

45 See P. de la Gorce, Histoire de la Seconde Republique, Volume I, Paris 1919, p. 78 91; Ch. Seignobos, Dzieje polityczne..., p. 150; M. Żywczyński, Historia powszechna 1789-1870, Warszawa 1975, p. 373.

46 See E. Driault, G. Monod, op. cit., p. 147.

47 Let us recall that on 25 July 1830, Charles X, the successor of Louis XVIII from 1824 , on the basis of a broad interpretation of his powers to issue ordonnances (Article 14 of the Constitutional Charter of 1814 granted the king, in urgent cases, the right to apply the so-called necessary rigours on his own initiative, which ensured state security and the implementation of laws), issued 4 ordonnances, in which: (1) he dissolved the newly elected Chamber of Deputies; 2) he ordered a new election; 3) he abolished the freedom of speech, prohibiting newspapers to publish anything without prior authorisation, which was to be sought separately by editors-in-chief and printers; 4) he changed the electoral law by depriving merchants and industrialists (patentés) of the active right to vote, limiting the circle of voters to large landowners. The last two ordonnances were a clear violation of the Constitution. The Ordonances were kept secret until the last moment. The guardian of the seals (the Minister of Justice) had their text printed at night, 
be deceived" ${ }^{48}$, and the people were assured that „The provisional government wishes to establish a republic - subject, however, to ratification by the people, who shall be immediately consulted. The unity of the nation (formed henceforth of all the classes of citizens who compose it); the government of the nation by itself; liberty, equality, and fraternity, for fundamental principles, and the people, for our emblem and watchword: these constitute the democratic government which France owes to itself, and which our efforts shall secure for it" ${ }^{\prime \prime}$.

However, the Provisional Government did not enjoy the full support of the left, especially that part of the left which demanded radical changes, especially changes of social nature ${ }^{50}$. Radical socialists led by Louis Blan-

and they appeared on 26 July only in the "Monitor", which, apart from journalists and the deputies, was hardly read by anyone. The news quickly spread around the city, causing widespread indignation and the outbreak of a revolution that was organised by progressive petty bourgeoisie, which supported the great bourgeoisie in the common front of the fight against the reactionary actions of King Charles X. More on the concept of royal ordonnances, see A. Klimaszewska, Ordonanse królewskie we Francji, „Czasopismo Prawno-Historyczne" 2017, no. 2, pp. 47-62.

48 This thread alludes to the events of 31 July 1830, when Louis Philip, the Duke of Orléans, who had been appointed, the day before, by the abdicating (in favour of his nineyear-old grandson) Charles $\mathrm{X}$ to the post of the general governor of the kingdom, entered Paris on horseback, greeted with applause and shouted: "Long live freedom! The fruit of the July Revolution of 1830, known as the Three Glorious Days, was appropriated by the bourgeoisie, which, contrary to the radical circles seeking to establish a republic, brought to the throne a representative of the younger Bourbon lineage. The first months of Ludwig Philip's bourgeois monarchy were already marked by unrest, more and more pronounced as the disappointment of the Parisian people grew. The July Monarchy would be a period of rapid development of capitalism, the expansion of industry and transport, and the creation of great fortunes of the bourgeois aristocracy and great financial circles.

49 Od Wiosny Ludów do wojny francusko-pruskiej (1848-1871). Teksty źródłowe, prepared by J. Frejlich, Kraków 1924, pp. 151-152. It should be stressed that the February Revolution in France surprised even the most revolutionary European democrats. The Committee of the Society for Democratic Unity and the Brotherhood of All Nations, based in Brussels, which included, among others, J. Lelewel and K. Marx, in an appeal dated 28 February 1848, claimed that "France has far exceeded our expectations", Do Obywateli Członków Tymczasowego Rządu Republiki Francuskiej, In: K. Marks, F. Engels, Dzieła, Volume IV, op. cit., pp. 835-836.

50 See E. Tersen, Le gouvernement provisoire et l'Europe, Paris 1948, pp. 13-17; Ch. Seignobos, Dzieje polityczne..., pp. 151-152. 
qui, the creator of a huge conspiracy organisation called the Society of Seasons, which was founded in 1838 and was now returning to the political scene, dynamically began to take action to influence the government by issuing an "Appeal to the Provisional Government" on 2 March, which demanded, inter alia, the abolition of money deposit and other obligations that the press had; the annulment of restrictions on the right of association and meetings; reform of the judiciary; the annulment of criminal legislation against workers' associations ${ }^{51}$. Some of these demands were later gradually realised by the Provisional Government, till the reaction and the outbreak of a new revolution in June 1848.

The first decision of the Provisional Government was the proclamation of a republic ${ }^{52}$. The government then adopted the principle of universal and secret voting, but only for men. The electoral law was regulated by the decree of March 5, 1848. The Provisional Government argued that it wanted to transfer the power exercised on behalf of the people to the new government as soon as possible ${ }^{53}$.

For this reason, elections, which were to be universal and direct, were to be held on 9 April. Article 6 reduced the census of age to 21, while Article 7 established the right to stand for election from the age of 25 , and voting was to be secret. The decree, introducing, above all, electoral equality and the end of census elections, provided that there would be about 9 million people entitled to vote, which indeed made France one of the largest democracies in the world at that time ${ }^{54}$. The aim of the National

51 See L.A. Blanqui, Wybór pism, translated by I. Bibrowska, B. Wścieklica, Warszawa 1975 , pp. 128-130.

52 See Ch. Seignobos, La Révolution de 1848 - Le Second Empire (1848-1859), In: E. Lavisse, Histoire de France contemporaine: depuis la Révolution jusqu’à la paix de 1919, Volume VI, Paris 1921, p. 9. As a reminder, let us point out that the First French Republic was proclaimed by the National Convention on 22 September 1792, one day after this parliamentary assembly had voted for the first time in French history to abolish the monarchy, see A. Mathiez, Rewolucja francuska, translated by W. Dzwonkowski, W. Łukaszewicz, T. Landecki, Warszawa 1956, pp. 282-283; W. Markov, A. Soboul, Wielka Rewolucja Francuzów 1789, translated by E. Morciniec, Wrocław 1984, pp. 208-209.

53 See A. Garrigou, Le brouillon du suffrage universel. Archéologie du décret du 5 mars 1848, „Genèses” 1991, no. 1, pp. 161-178, https://www.persee.fr/doc/genes_1155-3219_1991_num_6_1_1100 [retrieved: 27 September 2018].

54 See P. Bastid, L'avènement du suffrage universel, Paris 1948, p. 6. 
Assembly, elected on the basis of the new electoral law, was prepare a new constitution ${ }^{55}$.

In addition, the government abolished the death penalty for political crimes (which was meant to signify a symbol of dissociation from the horrors of the First French Republic) ${ }^{56}$, recognised full freedom of the press and association ${ }^{57}$, and abolished slavery throughout French territory on 27 April $1848^{58}$, starting with the island of La Réunion, which was one of French colonies ${ }^{59}$. The decree on the abolition of slavery provided for a period of two months from the announcement of the abolition of slavery until its entry into force. This was intended to enable slave-owners to complete the harvest of sugar cane without having to pay them ${ }^{60}$.

55 See J. Baszkiewicz, Historia Francji, Wrocław 1995, p. 485.

56 See Ch. Seignobos, La Révolution de 1848..., p. 15. The publication refers to, inter alia, the Law on Suspects of 17 September 1793 and the Law of 22 prairial year II (10 June 1794), see M. Konarski, Oblicza demokracji totalnej na przykładzie ustawodawstwa Wielkiej Rewolucji Francuskiej, In: Bezpieczeństwo. Prawo. Polityka, ed. M. Jurgilewicz, ed. T.Z. Leszczyński, ed. N. Malec, Kraków 2017, pp. 89-116.

57 See Ch Seignobos, La Révolution de 1848..., p. 37-40.

58 See ibidem, p. 23; L.C. Jennings, L'abolition de l'esclavage par la IIe République et ses effets en Louisiane (1848-1858), „Revue française d'histoire d'outre-mer” 1969, no. 205, p. 375-397, https://www.persee.fr/doc/outre_0300-9513_1969_num_56_205_1493 [retrieved: 26 September 2018].

59 The island is located in the Indian Ocean, approximately $700 \mathrm{~km}$ east of Madagascar and $174 \mathrm{~km}$ south-west of Mauritius. The emancipation of slaves on the island of La Réunion resulted in more than half of the population (55\%) regaining their freedom, i.e. 60318 inhabitants out of 108829 .

${ }^{60}$ Let us recall that already during the French Revolution slavery was abolished without compensation for the owners. The abolition took place on 4 February 1794 (16th pluviôse of year II of the Republic). On the attitude of French revolutionaries to slavery, see inter alia J.P Marat, Pisma wybrane, translated by K. Libera, Warszawa 1951, pp. 154-156; L. Saint-Just, O handlu i koloniach, In: idem, Wybór pism, translated by J. Ziemilski, B. Kulikowski, Warszawa 1954, p. 266. The law of February 4, 1794, unfortunately, was finally repealed by Napoleon I on May 20, 1802, which meant the restoration of slavery. However, after he was exiled to the island of Elbe, Emperor Napoleon I announced the immediate abolition of slavery on 29 March 1815, see Gaston-Martin, L'abolition de l'esclavage (27 avril 1848), Paris 1948, p. 10. His decision was confirmed by the Treaty of Paris of 20 November 1815. It should be added that as early as on February 8,1815 , eight countries adopted a declaration on the abolition of the slave trade, which the British used for further negotiations on the cessation of the transport of slaves 
Slavery throughout French territory was finally abolished at the request of the Alsace-based Undersecretary of State at the Ministry of Colony Affairs - Victor Schoelcher as late as on 27 April $1848^{61}$. Joseph-Napoleon SardaGarriga was given the task to effectively implement the decree of 27 April 1848. Despite opposition from the Colonial Assembly, he proclaimed the decree on 19 October and set 20 December as the date of emancipation of all slaves on the island.

In addition to the decisions of the Provisional Government ,which I listed above an urgent problem that had to be tackled immediately resulted from the difficult financial situation of the French people, mainly due to an industrial crisis and a growing banking crisis that I mentioned at the beginning of my discussion ${ }^{62}$. On 25 February, the people of Paris demanded recognition of the right to work, to which the government responded with a decree formulated by Louis Blanc, the provisions of which provided employment for every citizen ${ }^{63}$. In practice, however, this right to

across the Atlantic to the American plantations, see Declaration des 8 Cours, relative à l'Abolition Universelle de lat Traite des Nègres, 8 February 1815, British and Foreign State Papers, vol. 3 (1815-1816), 1838, p. 972; also cf.: Résolution relatives à l'Abolition de la Traite des Nègres, 28 November 1822, British and Foreign State Papers, vol. 10 (18221823), 1828, pp. 109-110.

61 See Gaston-Martin, op. cit., p. 61.

62 Out of a total of 350000 Parisian workers, 190000 (even 90\% in some industries) were made redundant during this period. On 15 March, the cash supply of the Bank of France fell to 59 and a half million, and on 6 March, on the opening day of the stock exchange, five percent securities, which at the beginning of the year reached the price of 116 francs, fell to 89 francs, and then to 50 francs, see Ch.H. Pouthas, Od 1815 do 1878 , In: G. Lefebvre, Ch.H. Pouthas, M. Baumont, Historia Francji, Volume II: od 1774 do czasów współczesnych, translated by M. Derenicz, Warszawa 1969, p. 302.

${ }_{63}$ See Ch. Schmidt, Des ateliers nationaux aux barricades de juin, Paris 1948, pp. 1417; P. de la Gorce, op. cit., pp. 116-117; Ch. Seignobos, La Révolution de 1848..., p. 11. In 1850, L. Blanqui, when he was already imprisoned in a prison in Doullens, reminisced L. Blanc's programme, writing that "Blanc had only one idea and only one goal: to create a ministry of progress at his disposal. It was almost a monomania, a passion to which he devoted himself completely. Everything that did not refer to the idée fixe or went beyond it in order to save the revolution, everything that aimed higher,was presented by him to to the masses as an obstacle, competition or hostile action", idem, op. cit., p. 164; cf. interesting remarks about L. Blanc made by A. Herzen, cited by J. Parvi i R. Śliwowski, Aleksander Hercen i Louis Blanc, „Przegląd Historyczny” 1970, no. 2, pp. 270-276. 
work was realised by the creation of the so-called national workshops ${ }^{64}$, in which the government employed 100,000 unemployed workers in poorly organised earthworks in Paris and the surrounding area ${ }^{65}$. As Marx wrote, "this beautiful name [of the national workshops - emphasis M.K.] was simply hiding the use of workers for boring, monotonous, unproductive earthworks for 23 sou of a day's pay. English "Workhouses ${ }^{66}$ under the open sky - this is what these national workshops were" ${ }^{67}$.

At the same time, the Provisional Government refused to create a Ministry of Labour and a Government Commission for Workers ${ }^{68}$, known as the Luxembourg Commission from its place of office in the Luxembourg Palace, which included representatives of both workers' unions and entrepreneurs ${ }^{69}$. The Commission prepared a programme of reforms which, however, were not implemented (workers' production associations, the nationalisation of mines, railway, insurance, public storage facilities for industrial production, large bazaars, agricultural colonies), etc. ${ }^{70}$. Finally, however,

64 See G. Lyon-Caen, J. Pélissier, Droit du travail, Paris 1988, p. 12.

65 See Ch. Seignobos, La Révolution de 1848..., pp. 44-47; E. Driault, G. Monod, op. cit., pp. 149-150.

66 The author quoted here refers to the The Poor Law Amendment Act 1834 (PLAA), enacted in Britain on 14 August 1834, which provided for - instead of benefits in kind or in cash - building workhouses for the poor, dubbed "Bastille" for the poor - which reflected the conditions in these workhouses, not much different than in prison, see M. Garbat, Pauperyzacja i powstanie polityki społecznej na przykładzie Anglii w epoce elżbietańskiej, „Nierówności społeczne a Wzrost gospodarczy” 2013, no. 34, p. 32; A. Piekarska, Ludowe państwo dobrobytu, „Praktyka Teoretyczna” 2015, no. 4, p. 233; N. McCord, The Implementation of the 1834 Poor Law Amendment Act on Tyneside, „International Review of Social History" 1969, vol. 4, pp. 90-108; G.R. Boyer, The economic role of the English Poor Law, 1780-1834, „Journal of Economic History” 1985, vol. 2, pp. 452-454; V. Care, The significance of a "correct and uniform system of accounts" to the administration of the Poor Law Amendment Act, 1834, „Accounting History Review” 2011, vol. 2, pp. 121-42.

${ }_{67}$ K. Marks, Walki klasowe we Francji od 1848 r. do 1850 r., In: K. Marks, F. Engels, Dzieła wybrane, Volume I, Warszawa 1949, p. 146; cf. Ch.H. Pouthas, op. cit., p. 306.

68 Zob. Le droit au travail au Luxembourg et a L'Assemblée Nationale, introduction E. de Girardin, Paris 1849, s. 1-2; Ch. Seignobos, La Révolution de 1848..., pp. 16-17.

69 See ibidem, pp. 47-49.

70 See J. Baszkiewicz, Historia Francji..., p. 487; W.H. Sewell, Corporations Républicaines: The Revolutionary Idiom of Parisian Workers in 1848, „Comparative Studies in Society and History" 1979, no. 2, pp. 195-203. 
the Luxembourg Commission succeeded in pushing through the decrees of 2 March reducing the working day to 10 hours in Paris and 11 hours elsewhere and limiting the exploitation of craftsmen's proletariat ${ }^{71}$.

The results of the social policy of the Provisional Government that did not match the expectations of the people, and the still unsolved economic crisis, caused a rift among the inhabitants of the newly established republic, which was reflected in the first demonstrations after the establishment of the republic, taking place in Paris on 16 and 17 March 1848, and then on 16 April in the name of the postponement of the elections to the National (Constitutional) Assembly and the National Guard, which were to be held on 9 April. Two petitions ( 6 and $14 \mathrm{March}$ ) and an appeal (17 March) were sent to the Provisional Government on this matter, but had no effect ${ }^{72}$.

As mentioned above, these actions (petitions, appeals) did not in any way alter the position of the Provisional Government, and the elections, which finally took place on 23 April $^{73}$, introduced nearly 900 MPs, 500 moderate and right-wing Republicans, 180 Orleanists, 100 Legitimists and only 100 socialists into the Assembly, with not a single peasant, due to the neglect of the rural electorate, as the rural population voted as indicated by the clergy and landowners who wanted to restore the old order ${ }^{74}$.

After the first meeting of the Assembly on May 4, 1848, the decision of the Provisional Government was confirmed and the republic was officially proclaimed again ${ }^{75}$, and on the next place the Provisional Government gave place to th Executive Committee, modelled on the Directorate, consisting of five persons ${ }^{76}$. According to Karl Marx, "not from 35 February,

71 See Le droit au travail..., s. 5-12; A.M. Wergeland, History of the Working Classes in France 1789-1870, „Journal of Political Economy” 1905, no. 3, p. 442; P. Vigier, op. cit., p. 20; F. Jarrige, B. Reynaud, La durée du travail, la norme et ses usages en 1848, „Genèses” 2011, no. 4, pp. 70-92, https://www.cairn.info/revue-geneses-2011-4-page-70. htm [retrieved: 27 September 2018].

72 See Ch. Seignobos, La Révolution de $1848 \ldots$, p. 54.

73 See ibidem, pp. 78-80.

74 See ibidem, pp. 82-84; P. de la Gorce, op. cit., pp. 213-214.

75 See P. de la Gorce, op. cit., pp. 226-227.

76 This body existed from 26 October 1795 (4 brumaire, year IV) until Napoleon's coup of 9 November 1799 (14 brumaire, year VIII) on the basis of the constitution adopted on 22 August 1795 (5 fructidor, year III). As we will see in the latter part of the article, it was not the only reference which the revolutionaries of 1848 made to the constitutional 
but from 4 May, a republic, recognised by the French people, has its origins. It is no longer a republic imposed by the Parisian proletariat on the Provisional Government; it is no longer a republic with social institutions; it is no longer the dream of the barricade fighters. The only rightful republic proclaimed by the National Assembly is not a revolutionary weapon against the bourgeois system, but rather its political renewal, the renewed political consolidation of the bourgeois society, is, in a word, a bourgeois republic" "77. These words were confirmed by F. Ziegler, who wrote that "the new National Constituent Assembly is haunted by the spirit of the July Monarchy"78. We must remember that this was still a period of exceptional social tension - the people were not satisfied with the Assembly, the national workshops were disappointing and the Luxembourg Commission would soon be dissolved (which happened on $16 \mathrm{May}^{79}$.

On 16 May there was a demonstration to support the Greater Poland Uprising and aid for Poland (people shouted "Long live Poland") ${ }^{80}$, which attracted an exceptional number of participants - over $100000^{81}$. The demonstration did not bring any positive results due to the fact that the Polish problems were pushed into the background. That was because the demonstration was transformed into an attempt to seize power by the democratic and socialist left ${ }^{82}$.

After that day, the Executive Committee reacted and issued a number of provocative decrees, e.g. a ban on mass gatherings; "the workers were openly provoked, jeered and derided" form the tribune of the National

models of the French Revolution. In any case, as S. Salmonowicz notices, "every day of the Spring of Nations was interpreted in the light of the experiences of the French Revolution”, idem, Rewolucja Francuska: blaski i cienie dziedzictwa, „Przegląd Historyczny” 1990, no. 1-2, p. 83.

77 K. Marks, Walki klasowe..., pp. 148-149; see J. Bainville, Dzieje Francji, translated by T. Stryjeński, Warszawa 1946, p. 428.

78 F. Ziegler, op. cit., p. 86.

79 See Ch. Seignobos, La Révolution de $1848 \ldots$, p. 92.

80 See P. de la Gorce, op. cit., pp. 249, 253.

81 See Ch. Seignobos, La Révolution de $1848 \ldots$, p. 92. J. Feldman writes more about the attitude of the French government to the Polish question. He draws attention to the duality of the French thought towards the Polish question, see idem, Sprawa polska w 1848 roku, Kraków 1933, pp. 95-96; E. Tersen, op. cit., pp. 28-44; J. Bainville, op. cit., p. 426.

82 See A. de Tocqueville, op. cit., pp. 135-10. 
Assembly ${ }^{83}$. But that was not all as at the same time the Executive Committee made it more difficult to access the national workshops, daily pay was changed into shift pay and the workers who were not originally from Paris were sent to Sologne (a region near Paris) ${ }^{84}$, supposedly to conduct earthworks (to clear forests and drain wetland). According to K. Marx, the workshops were described by the disappointed returning workers as "a rhetorical formula to console them after them after they had been exiled from Paris" 85 .

The intention behind the limitation of the workshops was to put pressure on workers in the capital to give up the idea of a democratic and social republic, which was a result of the significant influence of the right - mainly the industrial right, which hoped to overcome the resistance among manual workers in this way. As J. Baszkiewicz emphasises, "the aim was to cause a proletarian explosion through the closure of workshops and the drowning of Luxembourg's proposals; and by crushing it - to definitively knock the ideas of social reform out of workers' heads: production associations, nationalisation of railways, mines and insurance, progressive tax, universal and free basic education, etc." ${ }^{86}$. However, the final blow was delivered industrial to workers on 21 June 1848 by a decree which ordered all unmarried workers to be either expelled by force from national workshops or incorporated into the army. This meant that in practice this social group was in an impossible situation $^{87}$. The Spring of Nations in France entered a new stage.

\section{REFERENCES}

Bastid, Paul. 1948. L'avènement du suffrage universel, Paris: Presses Universitaires de France.

83 K. Marks, Walki klasowe..., p. 150.

84 See Ch. Seignobos, La Révolution de $1848 \ldots$, p. 100.

85 K. Marks, Walki klasowe..., p. 150.

86 J. Baszkiewicz, Historia Francji..., p. 489.

87 See P. de la Gorce, op. cit., pp. 325-326; Ch.H. Pouthas, op. cit., p. 307; C.E. Lida, The Democratic and Social Republic of 1848 and its Repercussions in the Hispanic World, In: The European Revolutions of 1848 and the Americas, ed. G. Thompson, London 2002, p. 50. 
Baszkiewicz, Jan. 1981. Wolność. Równość. Własność. Rewolucje burżuazyjne, Warszawa: Czytelnik.

Baszkiewicz, Jan. 1995. Historia Francji, Wrocław: Zakład Narodowy im. Ossolińskich; Bellona.

Bainville, Jacques. 1946. Dzieje Francji, transl. T. Stryjeński. Warszawa: Wydawnictwo J. Przeworskiego.

Blanqui, Louis August. 1975. Wybór pism, transl. I. Bibrowska, B. Wścieklica, Warszawa: Książka i Wiedza.

Boldenyi, János M. 1863. Dzieje Węgier pod względem historycznym, artystycznym, literackim i społecznym, transl. L. Rogalski, Warszawa: Nakładem Aleksandra Nowoleckiego.

Boyer, George R. 1985. „The economic role of the English Poor Law, 1780-1834”. Journal of Economic History 2: 452-454 [doi:10.1017/S0022050700034185 ].

Care, Verna. 2011. „The significance of a 'correct and uniform system of accounts' to the administration of the Poor Law Amendment Act, 1834". Accounting History Review 2: 121-142.

Ciepielewski, Jerzy. Kostrowicka, Irena. Landau, Zbigniew. Tomaszewski, Jerzy. 1974. Dzieje gospodarcze świata do roku 1970, Warszawa: Państwowe Wydawnictwo Ekonomiczne.

Czernyszewski, Mikołaj. 1959. Monarchia lipcowa, In: M. Czernyszewski, Wybór pism historycznych, transl. F. Borkowska, M. Wawrykowa, Wrocław: Zakład Narodowy im. Ossolińskich.

Deak, Istvan. 1979. The Lawful Revolution. Louis Kossuth and the Hungarians 1848-1849, New York: Columbia University Press.

Divéky, Adorjan. 1919. Węgrzy a Polacy w XIX stuleciu, Warszawa: Gebethner i Wolff.

Do Obywateli Członków Tymczasowego Rządu Republiki Francuskiej. 1986, In: K. Marks, F. Engels, Dzieła, Vol. IV, Warszawa: Książka i Wiedza.

Dziadzio, Andrzej. 2005. „Koncepcja państwa prawa w XIX wieku - idea i rzeczywistość". Czasopismo Prawno-Historyczne 1: 177-201.

Dziadzio, Andrzej. 2008. „Ochrona konstytucyjności prawa w Europie XIX wieku”. Studia z Dziejów Państwa i Prawa Polskiego 11: 169-183.

Engels, Fryderyk. 1960. Listy z Wuppertalu, In: K. Marks, F. Engels, Dzieła, Vol. I, Warszawa: Książka i Wiedza.

Engels, Fryderyk. 1961. Położenie klasy robotniczej w Anglii. Na podstawie własnych obserwacji i autentycznych źródeł, In: K. Marks, F. Engels, Dzieła, Vol. II, Warszawa: Książka i Wiedza.

Engels, Fryderyk. 1963. Niemiecka kampania o konstytucję Rzeszy, In: K. Marks, F. Engels, Dzieła, Vol. VII, Warszawa: Książka i Wiedza. 
Engels, Fryderyk. 1964. Rewolucja i kontrrewolucja w Niemczech, In: K. Marks, F. Engels, Dzieła, Vol. VIII, Warszawa: Książka i Wiedza.

Engels, Fryderyk. 1986. Rewolucja w Paryżu, In: K. Marks, F. Engels, Dzieła, Vol. IV, Warszawa: Książka i Wiedza.

Esmein, Adhemar. 1904. Zasady prawa konstytucyjnego, transl. K. Lutostański, W. Konopczyński. Warszawa: Wydawnictwo „Ogniwa”.

Felczak, Wacław. 1983. Historia Węgier, Wrocław: Zakład Narodowy im. Ossolińskich.

Garbat, Marcin. 2013. „Pauperyzacja i powstanie polityki społecznej na przykładzie Anglii w epoce elżbietańskiej”. Nierówności społeczne a Wzrost gospodarczy 34: 25-34.

Garrigou, Alain. 1991. „Le brouillon du suffrage universel. Archéologie du décret du 5 mars 1848". Genèses 1: 161-178, https://www.persee.fr/doc/ genes_1155-3219_1991_num_6_1_1100 [retrieved: 27 September 2018].

Gaston-Martin. 1948. L'abolition de l'esclavage (27 avril 1848), Paris: Presses Universitaires de France.

Gąsiorowska, Natalia. 1948. Sytuacja gospodarczo-społeczna na zachodzie i wschodzie Europy w połowie XIX stulecia, In: W stulecie Wiosny Ludów 1848-1948, Vol. I. Ed. N. Gąsiorowska, Warszawa: Państwowy Instytut Wydawniczy.

Gierowski, Józef Andrzej. 1999. Historia Włoch, Wrocław: Zakład Narodowy im. Ossolińskich.

Gorce de la, Pierre. 1919. Histoire de la Seconde Republique, Vol. I, Paris: Plon-Nourrit et Cie.

Grzybowski, Konstanty. 1947. Demokracja francuska, Kraków: Spółdzielnia Pracy i Użytkowników „Czytelnik”.

Handelsman, Mareli. 1948. „Rok 1848: przegląd zagadnień międzynarodowych”. Przegląd Historyczny 1948 38: 7-36.

Hobsbawm, Eric. 2013. Wiek rewolucji 1789-1848, transl. M. Starnawski, K. Gawlicz, Warszawa: Wydawnictwo Krytyki Politycznej.

Jarrige, François. Reynaud, Bénédicte. 2011. „La durée du travail, la norme et ses usages en 1848" Genèses 4: 70-92, https://www.cairn.info/revue-geneses2011-4-page-70.htm [retrieved: 27 September 2018].

Jennings, Lawrence C. 1969. „L'abolition de l'esclavage par la IIe République et ses effets en Louisiane (1848-1858)". Revue française d'histoire d'outremer 205: 375-397, https://www.persee.fr/doc/outre_0300-9513_1969_ num_56_205_1493 [retrieved: 26 September 2018].

Jones, Michael J. 2015. Jałowy pieniądz: historia kapitalizmu jako konfliktu między pracą a lichwą. Vol. III: od Wielkiego Głodu do krachu roku 2008, transl. J. Morka, Wrocław: Wydawnictwo „Wektory”. 
Kaczyńska, Elżbieta. Piesowicz, Kazimierz. 1977. Wykłady z powszechnej historii gospodarczej (od schyłku średniowiecza do I wojny światowej), Warszawa: Państwowe Wydawnictwo Naukowe.

Kann, Robert A. 1974. A history of the Habsburg empire 1526-1918, Berkeley: University of California Press.

Klimaszewska, Anna. 2017. „Ordonanse królewskie we Francji”. Czasopismo Prawno-Historyczne 2:47-62.

Konarski, Marcin. 2017. Zamach stanu w perspektywie prawno-historycznej na przykładzie Rewolucji Francuskiej 1789-1799, In: Przestępstwa przeciwko bezpieczeństwu i porządkowi publicznemu. Ed. W. Lis, Lublin: Wydawnictwo KUL.

Konarski, Marcin 2017. Oblicza demokracji totalnej na przykładzie ustawodawstwa Wielkiej Rewolucji Francuskiej, In: Bezpieczeństwo. Prawo. Polityka. Ed. M. Jurgilewicz, T. Z. Leszczyński, N. Malec, Kraków: Polskie Towarzystwo Geopolityczne.

Kosim, Jan. 1991. Prusy i inne kraje niemieckie po kongresie wiedeńskim, In: Europa i świat w epoce restauracji, romantyzmu i rewolucji 1815-1849. Ed. W. Zajewski, Vol. I, Warszawa: Państwowe Wydawnictwo „Wiedza Powszechna”.

Kulišer, Iosif Mihajlovič. 1961. Powszechna historia gospodarcza średniowiecza i czasów nowożytnych, Vol. II, transl. R. Winter-Rudnicki, Warszawa: Książka i Wiedza.

Kurt, Selim. 2014. „The Revolutions of 1848 and its reflections to modern political mentality”. Journal of History School” XVIII: 362-365 [http://dx.doi. org/10.14225/Joh506].

Le droit au travail au Luxembourg et a L'Assemblée Nationale. 1849. Introduction A. Lamartine, E. de Girardin, Paris: Michel Lévy frères, Libraires-Éditeurs.

Lewak, Adam. 1948. Emigracja Polska wobec rewolucji 1848/9 r., In: Pamiętnik VII Powszechnego Zjazdu Historyków Polskich we Wrocławiu 19-22 września 1948. Referaty, Vol. I, Warszawa: Polskie Towarzystwo Historyczne.

Lida, Clara E. 2002. The Democratic and Social Republic of 1848 and its Repercussions in the Hispanic World, [in:] The European Revolutions of 1848 and the Americas. Ed. G. Thompson, London: Institute of Latin American Studies. Lyon-Caen, Gérard. Pélissier, Jean. 1988. Droit du travail, Paris: Dalloz.

Maciejewski, Tadeusz. 2006. „Konstytucjonalizm habsbursko-niemiecki okresu Wiosny Ludów”. Gdańskie Studia Prawnicze. Studia z historii ustroju i prawa XV: 39-60.

Maciejewski, Tadeusz. 2006. „Konstytucjonalizm okresu Wiosny Ludów na obszarze Italii”. Gdańskie Studia Prawnicze. Studia z historii ustroju i prawa XV: 61-72. Marat, Jean-Paul. 1951. Pisma wybrane, transl. K. Libera, Warszawa: Książka i Wiedza. 
Markov, Walter. Soboul, Albert 1984. Wielka Rewolucja Francuzów 1789, transl. E. Morciniec, Wrocław: Zakład Narodowy im. Ossolińskich.

Marks, Karol. 1949. Walki klasowe we Francji od 1848 r. do 1850 r., In: K. Marks, F. Engels, Dzieła wybrane, Vol. I. Warszawa: Książka i Wiedza.

Marks, Karol. Engels, Fryderyk. 1963. Przegląd wydarzeń. Maj-październik 1850 r., In: K. Marks, F. Engels, Dzieła, Vol. VII. Warszawa: Książka i Wiedza.

Marriot, John Arthur Ransome, Robertson, Charles Grant. 1915. The evolution of Prussia, the making of an empire, Oxford: The Clarendon Press.

Mathiez, Albert. 1956. Rewolucja francuska, transl. W. Dzwonkowski, W. Łukaszewicz, T. Landecki, Warszawa: Książka i Wiedza.

Mehring, Franz. 1963. Historia socjaldemokracji niemieckiej, Vol. I, transl. E. Werfel, Warszawa: Książka i Wiedza.

McCord, Norman. 1969. „The Implementation of the 1834 Poor Law Amendment Act on Tyneside". International Review of Social History 4: 90-108.

Od Wiosny Ludów do wojny francusko-pruskiej (1848-1871). Teksty źródłowe. 1924. ed. J. Frejlich, Kraków: Krakowska Spółka Wydawnicza.

Parvi, Jerzy. Śliwowski, Réne. 1970. „Aleksander Hercen i Louis Blanc”. Przegląd Historyczny 2: 270-276.

Piekarska, Anna. 2015. „Ludowe państwo dobrobytu”. Praktyka Teoretyczna 4: 228-239.

Pouthas, Charles Hippolyte. 1969. Od 1815 do 1878, [in:] G. Lefebvre, Ch. H. Pouthas, M. Baumont, Historia Francji, Vol. II: od 1774 do czasów współczesnych, transl. M. Derenicz, Warszawa: Książka i Wiedza.

Rusiński, Władysław. 1973. Zarys historii gospodarczej powszechnej. Czasy nowożytne i najnowsze (1500-1949), Warszawa: Książka i Wiedza.

Saint-Just, Louis. 1954. O handlu i koloniach, In: L. Saint-Just, Wybór pism, transl. J. Ziemilski, B. Kulikowski, Warszawa: Książka i Wiedza.

Salmonowicz, Stanisław. 1990. „Rewolucja Francuska: blaski i cienie dziedzictwa”. Przegląd Historyczny 1- 2: 75-85.

Salmonowicz, Stanisław. 2004. Prusy: dzieje państwa i społeczeństwa, Warszawa: Książka i Wiedza.

Schmidt, Charles. 1948. Des ateliers nationaux aux barricades de juin, Paris: Presses Universitaires de France.

Schmitt, Carl. 2012. Teologia polityczna i inne pisma, transl. M.A. Cichocki, Warszawa: Wydawnictwo Aletheia.

Seignobos, Charles. 1899. Dzieje polityczne Europy współczesnej. Rozwój stronnictw i form politycznych 1814-1899. Ed. J. Stecki, Warszawa: Wydawnictwo „Głosu”. 
Seignobos, Charles. 1921. La Révolution de 1848 - Le Second Empire (18481859), [in:] E. Lavisse, Histoire de France contemporaine: depuis la Révolution jusqu'à la paix de 1919, Vol. VI, Paris: Hachette.

Sewell, William H. 1979. „Corporations Républicaines: The Revolutionary Idiom of Parisian Workers in 1848". Comparative Studies in Society and History 2: 195-203.

Tersen, Emile. 1948. Le gouvernement provisoire et l'Europe. Paris: Presses universitaires de France.

Tocqueville de, Alexis. 1987. Wspomnienia, transl. A.W. Labuda. Wrocław: Zakład Narodowy im. Ossolińskich.

Turpin, Dominique. 1992. Droit constitutionnele, Paris: Presses Universitaires de France.

Wawrykowa, Maria. 1980. Dzieje Niemiec 1789-1871, Warszawa: Państwowe Wydawnictwo Naukowe.

Wąsicki, Jan. 1986. Związek Niemiecki i państwa niemieckie 1815-1848, Poznań: Wydawnictwo Poznańskie.

Wąsowicz, Marek. 1994. Między tronem, giełdą i barykadą. Francja 1830-1848, Warszawa: Omnia.

Weill, Georges. 1912. La France sous la monarche constitutionnelle (1814-1848), Paris: Félix Alcan.

Wereszycki, Henryk. 1975. Pod berłem Habsburgów. Zagadnienia narodowościowe, Kraków: Wydawnictwo Literackie.

Wereszycki, Henryk. 1986. Historia Austrii, Wrocław: Zakład Narodowy im. Ossolińskich.

Wergeland, A.M. 1905. „History of the Working Classes in France 1789-1870”. Journal of Political Economy 3: 419-448.

Vigier, Philippe. 1970. La Seconde République. Paris: Presses Universitaires de France.

Zahorski, Andrzej. 1991. Francja w latach 1815-1848. Restauracja i Monarchia Lipcowa, In: Europa i świat w epoce restauracji, romantyzmu i rewolucji 1815-1849. Ed. W. Zajewski, Vol. I, Warszawa: Państwowe Wydawnictwo „Wiedza Powszechna”.

Ziegler, Gilette. 1972. Paryż i jego rewolucje, transl. H. Łochocka. Warszawa: Książka i Wiedza.

Żywczyński, Mieczysław. 1975. Historia powszechna 1789-1870, Warszawa: Państwowe Wydawnictwo Naukowe. 
